\title{
Textlinguistic Analysis of the Short Stories and Language Teaching, Sample of Eveline By Joyce*
}

\author{
Gülşen TORUSDAĞ $\breve{G *}^{* *}$
}

\begin{abstract}
Literary texts, which require special or unusual language, play an important role in language teaching. They have the traces of the real socio-cultural world surrounding them while they represent a fictional world. In these texts the most used words in daily life are sampled because they reflect human life. Short stories are appropriate to be used in language teaching because of their structural, linguistic properties and shortness. They have a powerful function in raising moral and ethical values in the classroom. Short fiction is a supreme resource for observing not only language but also life itself. Literary texts cannot be analyzed in first reading and they require a close reading from visible surface structure to invisible deep structure. While analyzing a short story through textlinguistic analysis method students reach the meanings in the deep structure of the text through lexical and grammatical elements on its surface structure. They learn words in their context and acquire grammatical knowledge in detail. They can actively use language and improve their abilities to produce and interpret text. In this study, as a sample, Eveline by Joyce will be analyzed through basic standards of the textuality, 'cohesion and coherence'.
\end{abstract}

Key words: Textlinguistics, microstructure, macrostructure, language teaching, Eveline, James Joyce.

\footnotetext{
* This article was extended from the article "Language Teaching Through Textlinguistic Analysis of the Short Stories: Sample of Eveline by Joyce" presented at I. Uluslararası Türk Kültür Dünyası Sempozyumu, 24-28 September 2017, Dubrovnik, Croatia.

** Asst. Prof. Linguistics Department, Van Yüzüncü Y1l University, Turkey.

Elmek:gtorosdag24@hotmail.com
} 


\section{Kısa Öykülerin Metindilbilimsel Analizi ve Dil Öğretimi Joyce'un Eveline Öyküsü Örneği}

\section{$\ddot{O} z$}

Özel ve sıra dışı bir dilin kullanıldığı yazınsal metinler, dil öğretiminde önemli bir rol oynarlar. Kurgusal bir dünyayı temsil ederken kendilerini çevreleyen sosyo-kültürel dünyanın izlerini taşırlar. İnsan hayatını yansıttıklarından bu metinlerde günlük hayatta en çok kullanılan sözcükleri görmek mümkündür. Yapısal, dilsel özellikleri ve kısa olmaları itibariyle kısa öyküler dil öğretiminde kullanılmaya uygun metinlerdir. Öyküler, öğrenci üzerinde ahlaki ve etik değerlerin oluşmasında güçlü bir işleve sahiptir. Kısa kurgu yalnızca dili değil hayatın kendisini gözlemlemek için de iyi bir kaynaktır. Yazınsal metinler ilk okumada çözümlenemeyen, görünen yüzey yapıdan görünmeyen derin yapıya doğru iyi bir okuma gerektiren metinlerdir. Bir kısa öyküyü metindilbilimsel olarak çözümlerken öğrenciler, yüzey yapıdaki sözcüksel ve dilbilgisel ögeler aracılı̆̆ıyla derin yapıdaki anlamlara ulaşabilirler. Sözcükleri bağlamlarında öğrenirler ve ayrıntılı bir gramer bilgisi edinirler. Dili aktif bir şekilde kullanabilir, metin üretme ve yorumlama becerilerini geliştirebilirler. Bu çalışmada, örnek olarak, Joyce'un Eveline adlı öyküsü metinselliğin temel ölçütleri olan 'bağlaşıklık ve bağdaşılılı' açısından çözümlenecektir.

Anahtar Kelimeler: Metindilbilim, küçük ölçekli yapı, büyük ölçekli yapı, dil öğretimi, Eveline, James Joyce. 


\section{Introduction}

A literary work is one of the human-specific communicative forms. While literary texts representing a fictional world they bore the traces of the real sociocultural world surrounding them. "Literary texts are products that reflect different aspects of society. They are cultural documents which offer a deeper understanding of a country or countries." "Short stories, like other literary types, are artworks that make think, feel, and have social, historical and political messages. They have a special place in the society culture they belong to. These texts have an aesthetic language and semantic richness.

In recent years the role of literature has gained importance within the field of language teaching. The literary texts are used both as a tool and as a purpose in language teaching. These texts chosen from the works of famous literary figures are useful for students because they have the best and most accurate use of language. As Gillian Lazar expressed, literature involves a special or unusual use of language and literary texts have multiple layers of meaning. They have also a powerful function in raising moral and ethical values in the classroom (2009: 3 - 5). Each level of foreign language study requires inclusion of literary texts (Krsteva - Kukubajska 2013: 3605).

In these texts the most used words in everyday life are sampled because they reflect human life. As Sage asserted, short fiction is also a supreme resource for observing not only language but also life itself. In short fiction, characters act out all the real and symbolic acts people carry out in daily lives, and do so in a variety of registers and tones (1987: 42). Short stories are appropriate for use in language teaching because of their structural, linguistic properties and shortness. These texts cannot be analyzed in first reading and they require a close reading from visible surface structure to invisible deep structure.

A literary text is a structure having two faces such as surface structure, which is what the text producer said and deep structure, which is what he/she

$1 \mathrm{http}: / /$ www.onestopenglish.com

Access Date: 18.02.2018 
wants to tell. Short stories are types in which many things are told in a few words. In this state, a short story producer uses all possibilities of the language such as connotations of the words besides their denotations, symbolic language uses, metaphors, literary arts, etc. That is why short stories are important literary types suitable for language teaching.

Since 60s, various text analysis methods have been improved. Theoretical approaches and applicable studies based on these methods showed that text could be approached from new angles. Text analysis is an applicable activity based on a theoretical basis. It is a fact that there are various methods to reach the meaning frames of the literary texts. Textlinguistics, from these methods, determines how the texts are fictionalized grammatically and contextually, their communicative functions, and demonstrates them with applicable samples. Today short stories are better understood, messages that writers would convey to their readers are more accessible through textlingustic analysis.

While analyzing short stories through textlinguistic criteria, especially according to cohesion standard, students encounter some cohesive, lexical elements on the surface structure of the text such as the reiteration of the same words, synonym, near synonym or antonym of the words, collocated words around a motive and grammatical reference items such as pronouns and their varieties, demonstrative and possessive adjectives, (personal suffixes at the end of predicates, possessive suffixes, genitive suffixes and accusative case suffixes at the end of nouns for an agglutinative language such as Turkish), connective elements, parallel sentence structures, grammatical tense concordances and aspects, inverse sentence samples having a functional structure. So, students can evaluate the differences between word types and word functions. At the same time they learn easily elliptic sentence structures and substitutions elements. It is better to teach grammatical elements in their textual contexts than to give intensive and tedious grammatical knowledge to students. In traditional text analysis, it is generally difficult to teach these grammatical devices. In addition words which are learned in textual context become more permanent in memory.

While analyzing a short story text according to coherence standard, students can reach easily to the layers of meaning of the text realized through surface 
structure elements, in its deep structure. Then they can communicate with text producer and understand message(s) he/she would to convey to text analyzer/ reader. Textlinguistic analysis contributes to the development of the vocabulary of the students; their evaluation of the text as a whole; their interpretation of the text by establishing relationships between linguistic elements and their speaking and text generation skill by discussion of the problems related to text. In both native and foreign language teaching, using language correctly and fluently is important as well as using the grammar of the language. In this context, analyzing short stories through cohesion and coherence standards of the textlinguistics that allow students to develop their basic language skills such as reading, writing, listening, and speaking and to learn the grammar of the language, to increase vocabulary is effective and popular method in language teaching.

For this reason textlinguistic analysis of a literary text especially 'short stories', has a function that makes learning easier in language teaching. As a short literary type that can be read in one sitting, students will not be bored when reading text and there will be no interruptions to prevent access to its layer of meanings as a whole. This shortness will improve the teacher chance of maintaining students' interest throughout a lesson. During the analysis of a long text, students, who have to struggle for too long with such text, may lose interest. As asserted by Sage, in language teaching short fiction makes the student's reading task and the teacher's coverage easier. As it is universal, all over the world students experience stories and can relate to them. And like all literature, it contributes to the development of cognitive analytical abilities, bringing the whole self to be relevant to a compressed account of a situation in a single place and moment. (1987: 43).

As Çetişli expressed, in literature education at the level of university, literature education should be text centered. In literature education, revealing, improving and enriching the aesthetic feelings and sensitivities of the young brains and souls; at the same time, while introducing them national and universal values, different cultures in an aesthetic framework, getting them notice the details and richness of the language should be aimed. (2006). Especially in Language and Literature Departments of the Universities, to have constantly the students analyze short stories by traditional methods lead to monotony in the teaching because in traditional short story analysis, usu- 
ally, the elements such as the life of short story writer, his/her literary movement and style, short story characters, setting, point of view and word arts are discussed.

Today, even if linguistic studies beyond sentence are realized under the name of 'textlinguistics' or 'discourse analysis', it is real that these two fields are intertwined and texts are accepted as both spoken and written form of the language. In this study without any dispute about the positions of these two fields relative to each other, an approach that unifies these fields will be accepted like Halliday and Hassan (1976). The basic unit of this study will be 'text'.

Halliday and Hasan suggest that "The word TEXT is used in linguistics to refer to any passage, spoken or written, of whatever length, that does form a unified whole. A text may be spoken or written, prose and verse, dialogue or monologue. It may be anything from a single proverb to a whole play, from a momentary cry for help to an all-day discussion on a committee." (1976: 1). As expressed by these writers, a text is best regarded as a semantic unit and a text does not consist of sentences but it is realized by, or encoded in, sentences. (Halliday - Hasan 1976: 2).

According to Öztokat, a text can be a sentence or a book. It is defined as an autonomous and closed structure. It has three dimensions such as verbal, syntactic and semantic. It is a coherent whole, structure formed from language elements and realized by process such as progress, continuity and reiteration. The elements that form a text are related to each other and the value of each element is defined according to relations between it and other elements. Text must be generated with the elements connected to each other and have a mechanism moving towards a certain result. (2005: $22-23)$. Aksan describes the text as "a whole of utterances connected to each other and to non-linguistic factors, realizing during a communication". (1993: 257). In Onursal's statement, a text is the greatest written or spoken language production occurred by the wholeness of meaning that are formed by sentence sequences connected to each other through criteria such as cohesion and coherence, produced for a certain communication, whose beginning and end are determined by the definite lines. (2003: 6).

In the opinion of Günay, while a sentence is handled as a unit of grammar, text is thought as a dynamic process whose communicative function should be 
considered. Text is a whole of linguistic system that has a communicative value; forms a closed structure with its beginning and end; is a meaningful structure in which linguistic signs come successively, and can be generated verbally or in writing. In other words text is a specific whole other than the total of the sentences that form it. (2007: 44 - 45).

A sentence is a unit that can be handled independently of the speaker; is formed from coherent words in them, and is a theoretical unit out of context. It is a fact depending on a syntactic order, which has definite rules. In definitions, it is expressed that a sentence alone has a judgment by itself and it is words series demonstrating wholeness but despite a sentence is right and complete in terms of grammar, it is seen that all sentences used in language are not sufficient to express a judgment completely. Though sentences are not within a context they have meanings but they get different meanings according to their context. For example, though the sentence "Say she was a fool, perhaps; and her place would be filled up by advertisement." alone is sufficient to expresses a judgment when it is considered out of text context it will be insufficient for the reader's understanding. These are incomprehensibilities caused by polysemy. A person who reads this above sentence out of context can ask some questions such as:

1- Who says?

2- Who was a fool?

3- Why was she fool?

4- What and where was her place?

The same sentence will make more meanings when it is read within textual context.

"What would they say of her in the Stores when they found out that she had run away with a fellow? Say she was a fool, perhaps; and her place would be filled up by advertisement."

When sentence is seen inadequate in linguistic analysis, linguistic studies are oriented to studies beyond sentence, text is focused on, and this leads to the birth of the textlinguistics. Textlinguistics handles textual relations by a holistic approach. In the light of this information James Joyce's Eveline will be analyzed 
through textlinguistic criteria, cohesion and coherence.

Eveline is a case story from James Joyce's Dubliners (published in 1914), which consists of fifteen short stories about Irish people portraying their lives in Dublin. Eveline is about a girl, Eveline Hill, stuck between choosing a life of regret with her father or going away and starting a new life with her lover. It is possible to see the sense of incompleteness of the case story in Eveline too.

Joyce is one of the most important English Modernist writers and the best innovator of the literary technique of the $20^{\text {th }}$ century. He was born in Dublin in 1882; he travelled a lot in France, Italy and Switzerland where he died in 1941. Eveline is fourth story of the Dubliners and the protagonist is on the borderline between adolescence and maturity. She is nineteen years old and works in a store, in Dublin. Her mother and her brother Ernest are dead. She lives with her father, who is a stingy, brutal and rude man against her, and her two young sisters. Her other brother Harry who is in church decorating business, is nearly always down somewhere in the country. She has to work hard, both in the house and at the business. At the same time she is responsible for the care of her two siblings. She has a hard life.

Eveline has love affair with a sailor, Frank, who wants to take her away and to marry her. Eveline who desires to escape a hard and monotone life is about to leave her home and to start a new life with her lover in Buenos Ayres. But she cannot forget her promise to her mother before her death, her promise "to keep the home together as long as she could." When Eveline meets Frank at the station to go away with him by the night-boat, suddenly, she decides not to go with Frank. Eveline's rejection of Frank is not just a rejection of love, but also a rejection of a new life in a distant unknown country. She desires to run away and to leave her past behind but she is too linked to her past. By fear of an unknown country and guilt against her father, she gives up on going away; her inner conflict does not let her to escape from Dublin, she prefers to live in her accustomed world.

\section{Textlinguistic Analysis on Eveline}

Textlinguistics that appears as a result of beyond sentence studies in contemporary linguistic researches aims to handle texts with its formal, structural, semantic and functional dimensions. Since 1970s in an analysis based on textlin- 
guistics that works as a different branch of the linguistics, connections between linguistic units, the structure of the text as whole and its function have become important not isolated sentences in a text. Textlinguistics determines standards and rules that make text all type of linguistic phenomenon. It identifies structural and functional characteristics of the text types. It studies relations between texts and real phenomena that they refer to and multilayers semantic structure of the texts. It tries to detect the functions that texts undertake according to their contexts.

According to Beaugrande and Dressler (1981), a text is defined as a communicative occurrence, which meets seven standards of textuality. For a sentence sequence to be text, these sentences have to form a wholeness of meaning by linking to each other by 'cohesion' and 'coherence' standards, to have standards such as 'intentionality', 'acceptability', 'informativity', 'situationality', 'intertextuality' and to be a spoken or written linguistic product whose beginning and end are determined by definite limits. In the opinion of Beaugrande and Dressler, "If any of these standards is not considered to have been satisfied, the text will not be communicative. Hence, non-communicative texts are treated as non-text." (1981: 3). "The cohesion of surface texts and the underlying coherence of textual worlds are the most obvious textual standards of textuality. They indicate how the component elements of the text fit together and make sense. However, they cannot provide absolute borderlines between texts and non-texts in real communication." (1981: 113). As supported by Şenöz, "cohesion and coherence from these standards, data from text type analysis are the most used indications of the textlinguistics." (2005: 60). On the other hand a text has to present a linguistic wholeness and to have a communicative function. In case of no communication a non-textual statement is used.

In the textlinguistic analysis of Eveline according to basic standards 'cohesion', which is on the surface structure of the text and 'coherence' on its deep structure, titles were formed as follows in the light of studies such as Halliday and Hasan (1976), Beaugrande and Dressler (1981), Dijk-Kintsch (1983), Günay (2007), Dilidüzgün (2008) and Erden (2010).

The structure of a text including basic textual features can be schematized as follows. Schema is adapted from the paper by Aydın and Torusdağ in Teke Dergisi (Sayı 3/4 2014) titled “Türkçe Öğretimi Çerçevesinde Yazınsal Bir Metin 
Çözümleme Örneği Olarak Refik Halit Karay'ın Garip Bir Hediye'si”.

\section{Schema 1. Text Structure}

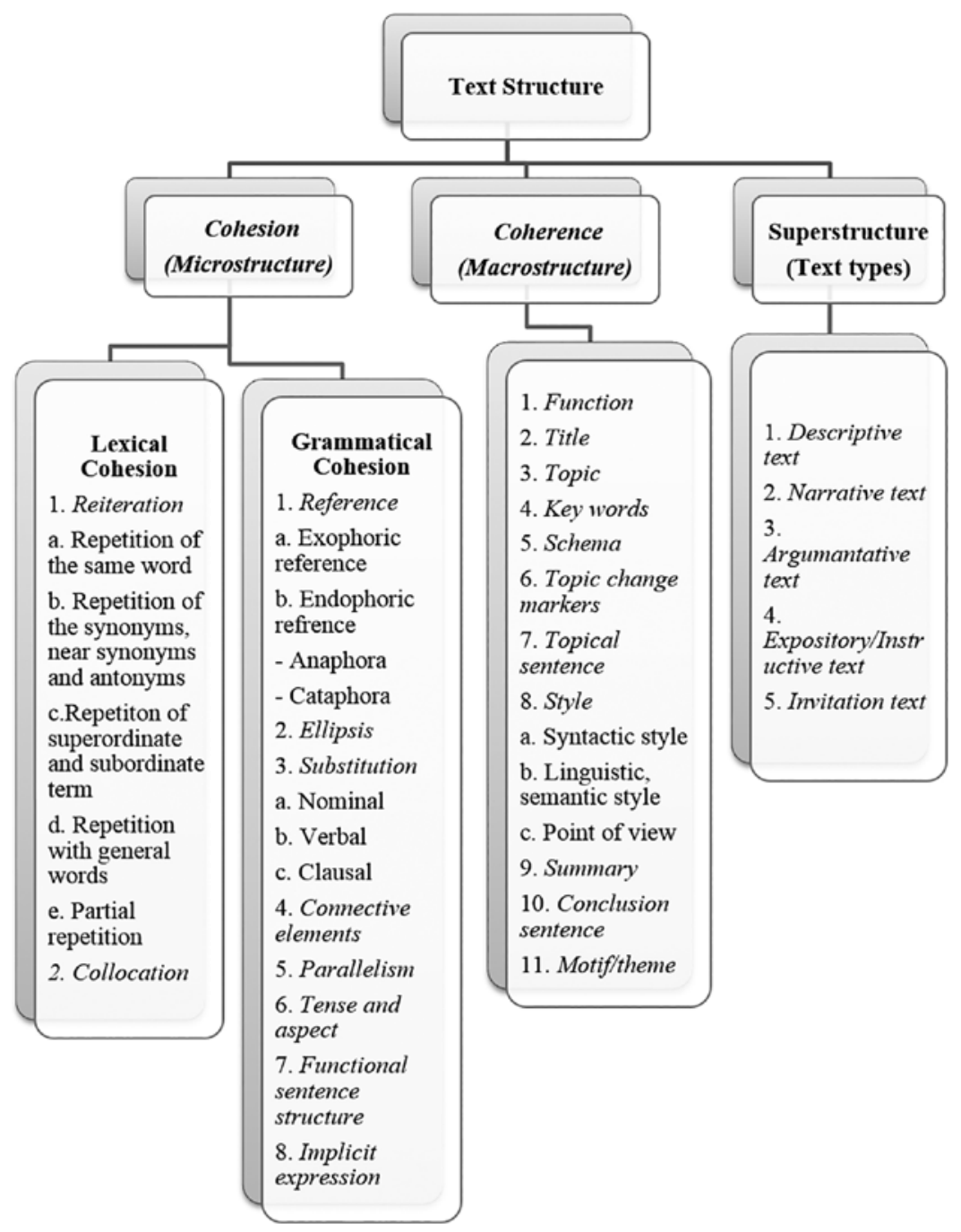


2. 1. Cohesion (Microstructure): In narrative texts none of the elements are alone or independent. Each linguistic structure becomes meaningful in relation to the other. Cohesion is related to the way the components of the surface text, that is, words we hear or see, interact with each other in a sequence. The surface components are related to each other according to grammatical forms and conventions. (Beaugrande - Dressler 1981: 3). In a text, cohesion is realized partly through grammar and partly through vocabulary. Cohesion is not mere formal relationship that does not include meaning. It is semantic relation but like all components of the semantic system, it is realized through lexicogrammatical system. In other words, it is a semantic relationship between an element in the text and another element that is very important in its interpretation. (Halliday - Hasan 1976: 5-6-8). In the words of Halliday and Hasan, "Cohesion does not concern what a text means; it concerns how the text is constructed as a semantic edifice." (1976: 26).

In this state there are two types of cohesion: Lexical and grammatical cohesion.

2. 1. 1. Lexical Cohesion: Lexical cohesion related to the use of the lexical elements in the microstructure of the text includes linguistic arrangements that prepare the macrostructure of the text. Studying on the cohesion of the texts that have linear and semantic continuity requires studying on the words of the text. But these words must be handled in their context. Because words have different contextual meanings out of their basic meanings when they are used in a context. According to Halliday and Hasan, lexical cohesion is handled under two main headings such as 'reiteration and collocation'. (1976: 288).

I. Reiteration: As Halliday and Hasan expressed, reiteration is "the fact that one lexical item refers back to another, to which it is related by having a common referent. Reiteration is a form of lexical cohesion which involves the repetition of a lexical item." (1976: 278). Repetitions are the most important linguistic devices supporting the cohesion of the text.

Eveline consists of 128 sentences. The story is shaped around the words 'Eveline' repeated 6 times with its co-references such as 'Miss Hill', 'Evvy' and personal pronoun 'she' (repeated 83 times), personal pronoun 'her' (repeated 22 times) and possessive adjective 'her' (repeated 60 times); Frank repeated 12 times with its co- 
references such as 'fellow', 'sailor', 'deck boy', 'lover' and personal pronoun 'he' (repeated 24 times), personal pronoun 'him' (repeated 9 times), possessive adjective his (repeated 7 times); 'father' repeated 12 times with its co-references such as personal pronoun 'he' (repeated 12 times) and possessive adjective 'his' (repeated 1 time); 'mother' repeated 9 times with its co-reference such as personal pronoun 'she' (repeated 2 times); 'home' repeated 10 times with its co-reference such as 'house' (repeated 8 times); to go away/to leave repeated 6 times.

a. Repetition of the Same Word: This is straightforward repetition of the lexical elements. The direct repetition of the same word is a cohesive device in the text. The words 'house', 'field' and 'father' have cohesive functions because they are repeated:

The man out of the last house passed on his way home; she heard his footsteps clacking along the concrete pavement and afterwards crunching on the cinder path before the new red houses. (5) Then a man from Belfast bought the field and built houses in it-not like their little brown houses, but bright brick houses with shining roofs.(7) The children of the avenue used to play together in that field - the Devines, the Waters, the Dunns, little Keogh the cripple, she and her brothers and sisters.(8) Her father used often to hunt them in out of the field with his blackthorn stick; but usually little Keogh used to keep nix and call out when he saw her father coming.(11) Her father was not so bad then; and besides, her mother was alive.(13) He had been a school friend of her father.(22) Whenever he showed the photograph to a visitor her father used to pass it with a casual word:(23)

b. Synonyms/Near Synonyms or Antonyms: Another cohesive device is the repetition of the synonym/near synonym or antonym of the words. This type of repetition causes the text to be fluid and qualified. These can be sampled as in the following sentences:

The man out of the last house passed on his way home; she heard his footsteps clacking along the concrete pavement and afterwards crunching on the cinder path before the new red houses. (5) The children of the avenue used to play together in that field - the Devines, the Waters, the Dunns, little Keogh the cripple, she and her brothers and sisters.(8) Was that wise?(26) In her home 
anyway she had shelter and food; she had those whom she had known all her life about her.(28) Of course she had to work hard, both in the house and at business. (29) How well she remembered the first time she had seen him; he was lodging in a house on the main road where she used to visit.(56) She trembled as she heard again her mother's voice saying constantly with foolish insistence:(92) She felt him seize her hand:(115) She gripped with both hands at the iron railing.(119) Her hands $\underline{\text { clutched }}$ the iron in frenzy.(123)

c. Superordinate - Subordinate Terms: The repetition of the words, related to each other by way of superordinate and subordinate terms, enriches the text in terms of words and makes it cohesive. In the following sentence superordinate term 'country' is repeated in the form of its subordinate term 'Buenos Ayres'.

But in her new home, in a distant unknown country, it would not be like that.(37) She was to go away with him by the night-boat to be his wife and to live with him in Buenos Ayres where he had a home waiting for her.(55)

In the following sentences superordinate term 'illness' is repeated in the form of its subordinate term 'craziness'.

She remembered the last night of her mother's illness; she was again in the close dark room at the other side of the hall and outside she heard a melancholy air of Italy.(87) As she mused the pitiful vision of her mother's life laid its spell on the very quick of her being - that life of commonplace sacrifices closing in final craziness. (91)

d. General Words: As a cohesive device, "The class of general noun is a small set of nouns having generalized reference within the major noun class, those such as 'human noun', 'place noun', 'fact noun' and the like. Examples are:

people, person, man, woman, child, boy, girl [human]

creature [non-human animate]

thing, object [inanimate concrete count]

stuff [inanimate concrete mass]

business, affair, matter [inanimate abstract]

move [action]

place [place] 
question, idea [fact]" (Halliday - Hasan 1976: 274). These items are important source of cohesion, especially in the spoken language.

As seen in the example, the general word 'children' is a general expression of 'the Devines, the Waters, the Dunns, little Keogh the cripple, she and her brothers and sisters'.

The children of the avenue used to play together in that field - the Devines, the Waters, the Dunns, little Keogh the cripple, she and her brothers and sisters. (8)

In the following sentences the general word 'work' is used in place of 'to keep the house together and to see that the two young children who had been left to her charge went to school regularly and got their meals regularly'.

She had hard work to keep the house together and to see that the two young children who had been left to her charge went to school regularly and got their meals regularly. (51) It was hard work - a hard life-but now that she was about to leave it she did not find it a wholly undesirable life.(52)

In the following sentences in place of the expressions 'to keep the house together' or 'to go away with him', in the $109^{\text {th }}$ sentences, the general word 'duty' is used.

She had hard work to keep the house together and to see that the two young children who had been left to her charge went to school regularly and got their meals regularly. (51) She was to go away with him by the night-boat to be his wife and to live with him in Buenos Ayres where he had a home waiting for her.(55) She felt her cheek pale and cold and, out of a maze of distress, she prayed to God to direct her, to show her what was her $\underline{\text { duty. }}$. (109)

e. Partial Repetition: The transformation of the words from verb to noun or adjective etc. forms the repetition chains and so a cohesive text is obtained. Beaugrande and Dressler suggest that partial recurrence requires using the same basic word-components but shifting them to a different word class (1981: 56). Partial recurrence is the repetition of the different word types generated from the same root (Dilidüzgün 2008: 76). In the following sentences the adjective 'unhappy' is repeated partially in the form of noun 'happiness' and the verb 'prayed' is repeated in the form of noun 'prayer'. 
Why should she be unhappy?(100) She had a right to happiness. (101) She felt her cheek pale and cold and, out of a maze of distress, she praved to God to direct her, to show her what was her duty.(109) Her distress awoke a nausea in her body and she kept moving her lips in silent fervent praver.(114)

II. Collocation: Halliday and Hasan suggest that the cohesion derives from the lexical organization of language. A word is associated with another word because it tends to occur in the same lexical environment. In this case these two words are collocated in the same context. (1976: 319). As asserted by Kiran and Eziler Kiran, collocation is the name of structural order formed by all of the words used to present or develop the same concept, to describe the same field of the reality, to express the same idea. (2010: 255). According to Dilidüzgün, another way of the cohesion in the text is to form related sentences to each other by collocating the words from the same conceptual field in the same context. (2008: 78). In general terms, the collocation of the words that are related to each other because they are used in the same context or the collocation of the words that are directly related to each other is another form of lexical cohesion.

In the story 'memory' motif is formed by the collocated words such as 'one time, then, together, usually, field, evening, children, man, house, roof, avenue, brick, brother, sister, father, stick, coming, brown, bright, shining, blackthorn, Keogh, happy, little, to play, to buy, to build, to grow up, to hunt, to keep nix, to call out, to see, to seem'.

'Home' motif is formed around the words from the same concept field such as 'room, dust, object, priest, photograph, harmonium, print, promise, Blessed Margaret Mary Alacoque, yellowing, hung, broken, coloured'.

'Father' motif is patterned by the collocation of the words such as 'nineteen, danger, father, violence, palpitations, girl, mother, sake, to grow up, to go for and to threaten'.

'Mother on her deathbed' motif is formed around the words 'night, illness, room, hall, outside, melancholy, air, Italy, organ-player, sixpence, sick-room, Italians, vision, life, spell, being, sacrifices, craziness, voice, foolish, insistence, strutting back, last, close, dark, damned, pitiful, commonplace, final, to hear, to remember, to be ordered, to go away, to be given, to muse, to lay, to tremble, to hear, 
constantly, Derevaun Seraun! (that means "At the end of pleasure, there is pain")2 'Money' motif is formed by the collocated words such as 'squabble, money, Saturday, night, wages, shilling, trouble, father, seven, street, Sunday, dinner, marketing, purse, hand, hard-earned, black, leather, crowds, load, provision, not to have head, to weary, to get, to squander, not to give, to throw, to buy, to rush out, to elbow, to return, unspeakably, quickly, tightly.

'Fellow/Frank' is described by the collocation of the words such as 'peaked cap, head, hair, face, kind, manly, open-hearted, pushed back, tumbled forward, bronze, fond of music'.

2. 1. 2. Grammatical Cohesion: Cohesion, which plays a special role in the creation of the text, means the continuity that exists between one part of the text and another. Grammatical cohesion is a type of cohesion that is realized by grammatical units, which are limited in number and form a closed system of the language. While creating a text, to be it a meaningful unity the sentences must have connections and relations in themselves; the thoughts must be expressed in relation to each other. In other words, grammatical cohesion is formed through grammatical connections between words, word phrases, verb tenses and sentences. As Halliday and Hasan suggested, a text is not a string of sentences. A text is not a simple grammatical unity but rather it is semantic unity. The unity that it has is the unity of meaning in context, a texture that expresses the fact that it relates as a whole to the environment in which it is placed. (1976: 293).

2. 1. 2. 1. Reference (Proform): As Beaugrande and Dressler asserted, cohesive devices are used to shorten and to simplify the surface text. One obvious cohesive device is the use of references, economical, short words. The bestknown reference elements are pronouns, which function in the place of the nouns, noun phrases with which they co-refer. (1981: 60). In every language there are certain items, which have the property of reference. That is instead of being interpreted semantically in their right; they make reference to something else for their interpretation. (Halliday - Hasan 1976: 31). Reference items can be exophoric or endophoric, if endophoric, they may be anaphoric or cataphoric. (1976: 33). In a text, a noun and all reference items, which refer it, have co-reference and 
the semantic interpretations of all co-referenced items are same. Beaugrande and Dressler suggest that co-reference is "relationship where different expressions activate the same text-world entity." (1981: 97). In every text there are anaphoric or cataphoric reference items that can be interpreted according to other elements. These are related to contextual situation and are used on behalf of language economics.

A. Exophoric Reference (Exophora): In the text, if the element on which semantic interpretation of the reference item based is in non-text world, this type of reference is exophoric. Halliday and Hasan denominate exophoric reference as situational reference and for them, "An exophoric item is one which does not name anything; it signals that reference must be made to the context of situation" and "exophoric reference is one form of context-dependence, since without the context we cannot interpret what is said". (1976: 33 - 35). Exophoric reference is not cohesive, since it does not bind the two elements of the text together. As Dilidüzgün asserted, though exophoric reference plays an important role in the formation of the text it has no function in the formation of relations between textual elements and so it is not handled as a device of cohesion. (2008: 60). Par example, when an author addresses the readers as 'the story you read is a real life story', the pronoun 'you' is an exophoric reference since it does not refer to a textual noun.

There is no exophoric reference in the story.

B. Endophoric Reference (Endophora): Generally, in any text every sentence, except the first, exhibits some form of cohesion with a preceding sentence, usually with the one immediately preceding, that is, every sentence contains at least one anaphoric connection which connects it with what has gone before, backward reference. Some sentences may also contain a cataphoric connection, which connects it with what follows, forward reference; but cataphoric references are very much rare, and are not necessary to the creation of the text. (Halliday Hasan 1976: 293)

a. Cataphoric Reference (Cataphora): The first sentence of the text starts with a cataphora done by a third person singular pronoun 'she'. This story character's identity is revealed as 'Miss Hill' in the $34^{\text {th }}$ sentence and as 'Eveline' in the $38^{\text {th }}$ sentence. 
She sat at the window watching the evening invade the avenue.(1)

In the $6^{\text {th }}$ sentence third person plural pronoun 'they' is a cataphoric reference of the nouns 'the Devines, the Waters, the Dunns, little Keogh the cripple, she and her brothers and sisters' in the $8^{\text {th }}$ sentence.

One time there used to be a field there in which they used to play every evening with other people's children.(6) The children of the avenue used to play together in that field - the Devines, the Waters, the Dunns, little Keogh the cripple, she and her brothers and sisters. (8)

\section{b. Anaphoric Reference (Anaphora)}

Anaphoric Reference with Personal Pronouns: In $10^{\text {th }}$ sentence third person singular pronoun 'he' is the anaphora of the word 'Ernest' in $9^{\text {th }}$ sentence and in the $33^{\text {rd }}$ sentence third person singular pronoun 'she' is the anaphora of the word 'Miss Gavan' in the $32^{\text {nd }}$ sentence.

$\underline{\text { Ernest, }}$ however, never played:(9) $\underline{\text { he }}$ was too grown up.(10) Miss Gavan would be glad.(32) She had always had an edge on her, especially whenever there were people listening.(33)

Anaphoric Reference with Demonstrative Pronouns: In the $42^{\text {nd }}$ sentence demonstrative pronoun 'that' is the anaphora of the word phrase 'her father's violence' in the $41^{\text {st }}$ sentence.

Even now, though she was over nineteen, she sometimes felt herself in danger of her

father's violence. (41) She knew it was that that had given her the palpitations.(42)

Anaphoric Reference with Reflexive Pronouns: In $41^{\text {st }}$ sentence reflexive pronoun 'herself' is an anaphora to the pronoun 'she' in the same sentence.

Even now, though she was over nineteen, she sometimes felt herself in danger of her father's violence.(41)

Anaphoric Reference with Possessive Pronouns: In the text there is not an anaphoric possessive pronoun.

Anaphoric Reference with Demonstrative Adjectives: In the $8^{\text {th }}$ sentence 'that field' is an anaphoric structure in the form of 'demonstrative adjective + noun' that refers to 'the field' in previous sentence. 
Then a man from Belfast bought the field and built houses in it-not like their little brown houses, but bright brick houses with shining roofs. (7) The children of the avenue used to play together in that field - the Devines, the Waters, the Dunns, little Keogh the cripple, she and her brothers and sisters.(8)

Anaphoric Reference with Possessive Adjectives: In $55^{\text {th }}$ sentence 'his wife' is an anaphoric structure in the form of 'possessive adjective + noun' that refers to 'Frank' in previous sentence.

Frank was very kind, manly, open-hearted.(54) She was to go away with him by the night-boat to be his wife and to live with him in Buenos Ayres where he had a home waiting for her.(55)

2. 1. 2. 2. Ellipsis: Ellipsis is another cohesive device contributing to compactness and efficiency of the text. In such a device the complete structure occurs before the elliptical one. (Beaugrande - Dressler 1981: 66-67). Ellipsis is the omission of an item. It can be interpreted as that form of substitution in which the item is replaced by nothing. (Halliday - Hasan 1976: 88).

It is matter of an ellipse of subject 'they' and modal verb 'would' in $31^{\text {st }}$ sentence, an ellipse of verb 'treated' in $40^{\text {th }}$ sentence

What would they say of her in the Stores when they found out that she had run away with a fellow?(30) (They would) Say she was a fool, perhaps; and her place would be filled up by advertisement.(31) She would not be treated as her mother had been (treated).(40)

2. 1. 2. 3. Substitution: As expressed by Halliday and Hasan, another type of cohesive relation is substitution, which is the replacement of one item by another. The distinction between substitution and reference is that substitution is a relation in the wording rather than in the meaning. Substitution is a relation, on the lexicogrammatical level, between linguistic items, such as words or phrases. Reference is a relation between meanings. There are three types of substitution: nominal, verbal, and clausal. The short list of the item that occur as substitutes is as follows:

Nominal: one, ones; same

Verbal: do

Clausal: so, not. (1976: 88 - 91). 
Substitution Based on Noun: In the $76^{\text {th }}$ sentence using 'one' and 'the other' in place of 'letters' in previous sentence is a substitution based on noun.

The white of two letters in her lap grew indistinct.(75) $\underline{\text { One }}$ was to Harry; the other was to her father.(76)

Substitution Based on Verb: In place of the verbs in the following sentences the verb 'to do' is used in $113^{\text {th }}$ sentence and a substitution based on verb is realized.

He used to meet her outside the Stores every evening and see her home.(60) He took her to see The Bohemian Girl and she felt elated as she sat in an unaccustomed part of the theatre with him.(61) People knew that they were courting and, when he sang about the lass that loves a sailor, she always felt pleasantly confused.(63) He used to call her Poppens out of fun.(64) He told her the names of the ships he had been on and the names of the different services.(68) He had sailed through the Straits of Magellan and he told her stories of the terrible Patagonians.(69) Could she still draw back after all he had done for her?(113)

Substitution Based on Clause: In place of $33-36^{\text {th }}$ sentences the expression 'like that' is used and text cohesion is formed while an economic language is used at the same time boring repetitions are avoided.

She had always had an edge on her, especially whenever there were people listening. (33) "Miss Hill, don't you see these ladies are waiting?"(34) "Look lively, Miss Hill, please.”(35) She would not cry many tears at leaving the Stores.(36) But in her new home, in a distant unknown country, it would not be like that.(37)

2. 1. 2. 4. Connective (Junctive) Elements: Texts are structures made up of syntactic and semantic connections between multiple sentences. In a text, connection is made up both grammatically and by establishing logical links between events. Subject and meaning unity is formed through junctive elements that have no meaning alone and are useful for establishing formal and semantic connections between the parts of the sentence or text in which they are.

As Beaugrande and Dressler suggested, "A clear device for signaling the relationships among events or situations is junction, the use of junctive expression (in traditional grammars rather indiscriminately all called "conjunctions"). For the writers there are at least four major types of junctions: 
Conjunction links things which have the same status, e.g. both true in the textual world.

Disjunction links things which have alternative status e.g. two things of which only one can be true in the textual world.

Contrajunction links things having the same status but appearing incompatible in the textual world, e.g. a cause and an unanticipated effect.

Subordination links thing when the status of one depends on that of the other, e.g. things true under certain conditions or for certain motives (precondition/event, cause/effect, etc.) (1981: 71).

Halliday and Hasan suggest four headings for conjunctive relations:

Additive: and, and also, nor, and... not etc.

Adversative: yet, though, but, however, nevertheless etc.

Causal: so, then, therefore, because of this, for this reason etc.

Temporal: then, next, after that, previously, finally etc. (1976: 243).

In Eveline connective elements 'and' is used 46 times, 'but' 10 times, 'that' 10 times, 'then' 8 times, 'or' 2 times, 'yet, however, afterwards, besides' 1 time.

2. 1. 2. 5. Parallelism: Parallelism is a cohesive device which requires reusing surface formats but filling them different expression. (Beaugrande Dressler 1981: 57). In other words, it is the repetition of the same structure with different contents.

In the following sentences, there is a parallel sentence structure such as 'subject + modal verb would + main verb'.

But in her new home, in a distant unknown country, it would not be like that.(37) Then she would be married-she, Eveline.(38) People would treat her with respect then.(39) She would not be treated as her mother had been.(40)

2. 1. 2. 6. Tense, Aspect: In text analysis, grammatical and fictional tenses are clues to understand the events of the story. In this text as grammatical tenses, simple past and past perfect tenses are used at most especially when describing past events. Simple present tense is used especially in a few direct speeches and past continuous tense, which demonstrates continuity in the past, is used in a few sentences. 
In the story almost nothing happens in the present of the story, everything happens in Eveline's mind. At the beginning of $20^{\text {th }}$ century, there is a new concept of time in narrative texts that moves backward and forward with freedom, trying to capture the sense of time as it actually operates in the human consciousness. In the text there are some expressions indicating time such as 'She sat at the window watching the evening invade the avenue.(1), She was to go away with him by the night-boat to be his wife and to live with him in Buenos Ayres where he had a home waiting for her.(55), The evening deepened in the avenue.(74)'. Thus the fictional tense of the story is placed on a short time, which begins when Eveline sits at the window on the eve of a decision watching 'the evening invades the avenue' and ends when she goes to the station to escape with her lover by the night-boat in the same evening.

2. 1. 2. 7. Functional Sentence Structure: To show the importance or newness of an expression the ordering of the sentence can be changed. Beaugrande and Dressler designate this device as 'functional sentence perspective'. "This designation suggests that sentence elements can "function" by setting the knowledge they activate into a "perspective" of importance or newness. In many languages, for instance, elements conveying important, new, or unexpected material are reserved for the latter part of the sentence." (1981: 20). "Since people tend to give a point of orientation before presenting new or surprising things, informativity tends to rise toward the end of a clause or sentence." (1981: 75).

Her head was leaned against the window curtains, and in her nostrils was the odour of dusty cretonne.(2) Amid the seas she sent a cry of anguish.(124)

2. 1. 2. 8. Implicit Expression: According to Günay, every language has its own specific uses. By means of these uses information in the text can be conveyed to the reader both explicitly and implicitly or through implicatures and presuppositions. Information not explicitly stated by the writer is given through implicatures described as language skill (2007: 86 - 87). Even for the simplest texts to be understood the readers have to make inferences by using general information acquired by world knowledge and cultural backgrounds. Implicatures, which are suitable to short story nature, are stylistic feature of the writer. They include information to be gained through semantic or logical reasoning. 
She had consented to go away, to leave her home.(25) Was that wise?(26) She tried to weigh each side of the question.(27) In her home anyway she had shelter and food; she had those whom she had known all her life about her.(28) Of course she had to work hard, both in the house and at business. (29) But in her new home, in a distant unknown country, it would not be like that.(37) Then she would be married -she, Eveline.(38) People would treat her with respect then.(39) She would not be treated as her mother had been.(40)

From the above sentences we can infer Eveline's dilemma, to go away or to stay at home; her despair and indecisions; Joyce's picture about the life of $19^{\text {th }}$ century women in a patriarchal society in Dublin. Furthermore, Eveline's hopes about her future are suggested in the final three sentences. And we can infer her fear of living as a stereotypical woman forces her to decide to leave with her lover.

And yet during all those years she had never found out the name of the priest whose yellowing photograph hung on the wall above the broken harmonium beside the coloured print of the promises made to Blessed Margaret Mary Alacoque.(21) She felt her cheek pale and cold and, out of a maze of distress, she prayed to God to direct her, to show her what was her duty.(109)

From the above sentences, Eveline's true faith in God, and her and her family's religious feelings can be inferred.

When they were growing up he had never gone for her like he used to go for Harry and Ernest, because she was a girl; but latterly he had begun to threaten her and say what he would do to her only for her dead mother's sake.(43)

From above sentences it can be inferred that Eveline's father does not love her enough or he does not go for her like he goes for her brothers, Harry and Ernest. It is suggested that as in many societies, the daughters are not loved in the society where Eveline lives, either.

Besides, the invariable squabble for money on Saturday nights had begun to weary her unspeakably.(46) She always gave her entire wages — seven shillings-and Harry always sent up what he could but the trouble was to get any money from her father.(47) He said she used to squander the money, that she had no head, that he wasn't going to give her his hard-earned money to throw about the streets, and much more, for he was usually fairly bad on Saturday night.(48)

In the above sentences it is suggested that Eveline's father is a mean man. 
It was hard work - a hard life-but now that she was about to leave it she did not find it a wholly undesirable life.(52) She stood up in a sudden impulse of terror.(94) Escape!(95) She must escape!(96)

From the above sentences Eveline's indecision, hesitations and her tides can be inferred.

She remembered her father strutting back into the sick-room saying:(89) "Damned Italians! coming over here!"'(90)

From the above sentences the racist thought of Eveline's father can be inferred.

Of course, her father had found out the affair and had forbidden her to have anything to say to him.(71) "I know these sailor chaps," he said.(72)

From the above sentences we can infer Eveline's father is a conservative and authoritarian man and he does not trust sailors.

She trembled as she heard again her mother's voice saying constantly with foolish insistence:(92) “Derevaun Seraun! Derevaun Seraun!”(93)

In the $93^{\text {rd }}$ sentence, there is "A phrase that could be two things: either a phrase James Joyce made up for the story, or a rendering of Irish Gaelic that means, "At the end of pleasure, there is pain". Her mother could be saying this to her to warn her that though things may seem good to Eveline at that moment, at the end it will be worse."3

She felt her cheek pale and cold and, out of a maze of distress, she prayed to God to direct her, to show her what was her duty.(109) Her distress awoke a nausea in her body and she kept moving her lips in silent fervent prayer.(114) All the seas of the world tumbled about her heart.(117) He was drawing her into them: he would drown her.(118) Amid the seas she sent a cry of anguish.(124) She set her white face to him, passive, like a helpless animal.(128) Her eyes gave him no sign of love or farewell or recognition.(129)

In the above sentences it is suggested that due to her love, respect and responsibility towards her family, Eveline sacrifices herself, and cannot go away. Her ties to the past, her promises to her mother create in Eveline inability to change the course of her life. At the same time Eveline's fear of the distant, un- 
known country and her doubts about Frank combine with her attachment to her environment and her feelings of guilt and she can not be sure about her desire to escape. A sort of paralysis case in the face of despair can be inferred.

2. 2. Coherence (Macrostructure): Texts are not understood only through microstructural analysis. Macrostructural analysis is needed to reach the general meaning of the text. In the texts macrostructures are semantic objects. In text analysis there is a structure from the surface to the deep. Surface text is visible, concrete and what text producer said while deep structure is invisible, abstract and what he/she wanted to say. Semantically coherent structures in the deep of the texts are reached through lexical and grammatical cohesive structures on the surface of the text. In a textual analysis all the elements of the surface texts are meaningful in relation to each other not alone.

For the understanding of the text there should be a parallelism between the world knowledge of the text analyzer and textual concepts and relations. As quoted from Halliday and Hasan, "Language can be explained as a multiple coding system comprising three levels of coding, or 'strata': the semantic (meaning), the lexicogrammatical (forms) and the phonological and orthographic (expressions). (1976: 5). Text producer forms the text through this coding system and text analyzer divides it into its parts, establishes relations between them and decodes this coding. Because of their artistic features, literary texts are difficult to understand than non-fictional texts and they require more knowledge, experience and effort. As supported by Dijk and Kintsch, for the understanding of a text, text analyzer should derive macropropositions from the text. For the derivation of the macropropositions text analyzer should have enough world and text types knowledge. Since text is about real or fictitious possible worlds, our knowledge of the world and cultural background may supply us with expectations or predictions about what possibly may occur. (1983:196 - 197).

As expressed by Dijk, "much of the information of a text is not explicitly expressed, but left implicit. Words, clauses, and other textual expressions may imply concepts or propositions, which may be inferred on the basis of background knowledge. There are various types of implication: entailments, presupposition, and weaker forms, such as suggestion and association.” (2002: 113 - 114). By the 
expression of Beaugrande and Dressler, "Coherence is clearly not a mere feature of texts, but rather the outcome of cognitive processes among text users. The adding of one's own knowledge to bring a textual world together is called inferencing." (1981: 6). Text user may understand through inferences what text producer suggested. Coherence is wholeness that is continuity of logical and semantic concordance in the text. Analyzing a text in terms of coherence is to evaluate whole text semantically. There must be semantic relation and coherence, directly or indirectly, between all linguistic units of the text. Every new information must be related or contribute something to the previous ones.

2. 2. Function: Text is a form of language use created for specific communicative purposes. Short stories are also means of communication between their authors and readers. The function of a text can be to inform, to make think, to tell a story, to amuse, to excite, to describe, to prove, to criticize and to provide thought development and change.

For Günay, each text thus every narrative text has a function. In the same text there are also different functions. Each narration has an informative function for its reader. This informative function is more marked in the narrations, which refer to the real world, such as newspaper interviews, biographies, autobiographies, historical narrations. Because narrative texts whose references are on them such as tale, story, epic and novel are based on fiction, each narrative text has a fictional function. Various stylistic structures based on figure of speech, rhetoric, connotation and image indicate the artistic function of the narrative texts. In narrative texts there can also be proving function. The author can use special narration forms and examples to convince reader. (2007: 238 - 239).

The function of the short story Eveline can be to tell a story, to make reader think about a social event such as woman's situation in a patriarchal society, or to create a thought or behavior change in the reader. Besides all these, its main function can be to compare modernism and tradition; their good and bad sides and human hesitations in the acceptation of modernism as it is, without thinking.

2. 2. 2. Title: Title is the name of the text. Title expressed concisely is defined as limited information about the subject of the text. It is important for reader and as Dijk and Kintsch expressed, "the top level o the macrostructure may sim- 
ply be expressed by the title”. (1983: 53). According to Günay, title is preliminary expression of all the information about text. It gives the reader condensed and short information about text. It has information and call function. A well-chosen title awakens reading request in the readers but a poorly chosen title can awaken indifference in them. (2007: 58).

2. 2. 3. Topic: Authors convey their messages to readers by means of the topic they choose. For author the topic is a raw material or tool to process. Topic is what is told in a text. By Erden's expression, topic is a functional concept since it has communicative aim and dynamism and it is a tool to reach basic theme. An author has to choose the right and suitable topic to text type and reader's communicative context and socio-cultural condition. In case story individual and social thoughts, emotions and dreams are in foreground. It does not carry anxiety of arising curiosity and excitement in the reader. Topic is not based on any event, does not take its force from being interesting; it presents a section of life or a human case in a specific environment. (2010: 46-55).

After the death of her mother, the indecision of a girl, who has a hard life beside her father who is brutal and stingy man, about running away with her fellow or staying at home with her father, is the topic of this story.

2. 2. 4. Key Words: Key words are the words repeated throughout the story and needed to determine the topic and to resume the story. The texts are formed around these key words. The key words of the story are the most repeated words with their co-references such as 'Eveline, Frank, father, mother, home, to go away/to leave'.

2. 2. 5. Schema: Texts are treated structurally, semantically and functionally. Text writer has to form his/her thoughts that $\mathrm{s} / \mathrm{h}$ e wants to convey to readers in a logical and semantic order. The schema of the text depends on text type. The story schema aids the formation of the macrostructure. According to Dijk and Kintsch, besides the surface structural and semantic information, schematic or superstructural information may strategically help the derivation of macropropositions. This is because, first of all, many schematic structures, such as those of narrative, have a normal or canonical ordering, and second, because the schematic categories have global semantic constraints. If, indeed, the beginning of a story is 
schematically organized by a setting, for example, the first macroproposition(s) may denote a state description, introducing participants, place, and time specifications, and backgrounds or motivations for the events or actions that follow. (1983: 206). As Erden expressed, the plan of the stories is related to the sequence of the events and the sequences of people involved in the events. The traditional stories have a planned structure. The planned structure has sections such as exposition where the knowledge (what the story is about, conditions, place and time) is introduced. Complication is the section where are the problems that main characters encounter and their inner conflicts in the face of these problems, their problems with other people. Some stories may not have important events; in this case, they may not have complication. As a rule in the climax close to the end of the story, complication is at the highest level. In the resolution section soon after the climax, sometimes, solutions can be difficult to understand, do not feel a sense of completeness in the reader. Sometimes a story can be ended unexpectedly with the climax. (2010: 29).

In a story the initial part is very important. As it is known many stories begin with a dialogue. Sometimes a story begins with a character and sometimes the description of the place forms the best start so the reader feels himself in that place. Though in the case stories there are not classical introduction, body, conclusion sections, when considered that the events are narrated in a logical order, in all stories, it is possible to determine a short introduction, a long body and a conclusion a bit long than the introduction.

The introduction of this story is from the $1^{\text {st }}$ sentence to the $24^{\text {th }}$ sentence. In this section Eveline's sitting at a window in her home watching the evening invade the avenue and few people on the way is depicted. With a flashback, she goes back to her childhood, thinks about her father who was not so bad then, friends who went away or her mother who died. She looks round the room. While reviewing all the familiar objects in the room, with a flashforward she thinks she would never see these objects and, with a flash back, she had never found out the name of the priest whose photograph is hung on the wall.

The development of the story is from the $25^{\text {th }}$ sentence to $73^{\text {rd }}$ sentence. This section can be divided into three parts. In the first part, from the $25^{\text {th }}$ sentence 
to $37^{\text {th }}$ sentence, again, she is in the present of the story. Now it is time to go away for her. With a flashforward, she thinks about ones who would say that she was a fool if she goes away with her fellow. With a flashback she remembers Miss Gavan who has always an edge on her in the Stores and with a flashforward Eveline supposes she would not cry at leaving the Stores. In the $37^{\text {th }}-40^{\text {th }}$ sentences flasforwards go on and Eveline imagines she would be treated with respect in her new home, in a distant unknown country. In the $41-42^{\text {nd }}$ sentences Eveline's father is demonstrated as Eveline's today palpitations cause. From the $43^{\text {rd }}$ sentence to the $52^{\text {nd }}$ sentence with a flashback Eveline remembers her growth period and her father's brutal behaviors and stinginess. She has to work in the house and at business to keep the house together and has to care for her two young sisters. Her life is hard but while she is about to leave home she does not find it wholly undesirable life.

From the $53^{\text {rd }}$ sentence to $82^{\text {nd }}$ sentence is the second part of the development. In this part Frank, Eveline's fellow is presented. He is a sailor and wants Eveline to go away with him to Buenos Ayres. She is about to explore a new life with him. With a flashback she remembers the first time she saw him and the meeting with him secretly. In $74^{\text {th }}$ sentence Eveline is again at the present of the story, while the evening deepens she prepares two letters for her brother Harry and father. She notices that her father became old and with a flashforward she thinks he would miss her. With a flashback she remembers her father's good behaviors for her in the past.

The final part of the development is from the $83^{\text {rd }}$ sentence to the $103^{\text {rd }}$ sentence. In $83^{\text {rd }}$ sentence Eveline is at the present of the story, while sitting by the window she hears a street organ playing and with a flashback she goes back to the last night of her mother's illness and remembers her promise to her mother, to keep the home together as long as she could. Her mother's voice is in her ears, repeating constantly the same words with foolish insistence. Suddenly she decides to escape with Frank and with a flashforward she imagines he would save her, give her life perhaps love, too.

The conclusion of the story is from the $104^{\text {th }}$ sentence to the $129^{\text {th }}$ sentence. In this section Eveline is in the station at the North Wall to escape with Frank by 
the night-boat to be his wife and to live with him in Buenos Ayres. But she feels her cheek pale and cold and prays to God to direct her, to show her duty. Her distress awakes nausea in her body. While Frank calls her she set her white face to him passive, like a helpless animal. Her eyes give him no sign of love or farewell or recognition.

2. 2. 6. Topic Change Markers: Texts are structured according to a certain order as a requirement of their fiction. As Dijk and Knitsch asserted, episodes are surface structure mark that signals topic change. Episodes may be marked in different ways but a well-known surface structure mark is paragraph or pause in spoken language. There are signals other than those surface structures for example; an episode is often introduced in semantically remarkable ways such as new places, times, objects or possible worlds signaling topic change. Examples of topic change markers at the beginning of new episodes are:

1- Change of possible world: $X$ dreamt, pretended, ... that ...

2- Change of time or period: The next day... The following year...

3- Change of place: (In the meantime) in Amsterdam ...

4- Introduction of new participants

5- Full noun phrase reintroduction of old participants

6- Change of perspective or point of view

7- Different predicate range (change of frame or script). (1983: 204).

In the story, 'few people' as a new participant, 'one time, a long time ago' as a change of time, 'home' as a change of place, 'She had consented to go away, to leave her home.' as a different predicate range, 'store, new home, a distant unknown country', as a change of place, 'now' as a change of time, 'father' as an old participant, 'Frank' as a new participant, 'father' as an old participant, 'evening, not long before, another day' as a change of time, 'organ' as a new participant, 'mother' as an old participant, 'She stood up' as a new predicate, 'Frank' as an old participant, 'station' as a change of place are determined as topic change markers.

2. 2. 7. Topical Sentence: One time there used to be a field there in which they used to play every evening with other people's children.(6) is a topical sentence indicating information to present about Eveline's childhood. 
Now she was going to go away like the others, to leave her home.(17) is a topical sentence indicating Eveline's wish to run away from her home.

She had consented to go away, to leave her home.(25) Was that wise?(26) are topical sentences informing about Eveline's hesitance for leaving her home.

But in her new home, in a distant unknown country, it would not be like that.(37) is a topical sentence informing Eveline's status before and after her marriage would be told.

She was about to explore another life with Frank.(53) This topical sentence informs that Frank and his relation with Eveline would be presented and their plans to go to Buenos Ayres would be told.

Down far in the avenue she could hear a street organ playing.(84) She knew the air.(85) are topical sentences indicating a melody of an organ reminded Eveline the death night of her mother would be told.

Escape!(95) She must escape!(96) She stood among the swaying crowd in the station at the North Wall.(104) These topical sentences inform that Eveline decided to escape with her fellow and her final situation in the station at the North Wall would be told.

2. 2. 8. Style: Literary texts sample the aesthetic and multi-meaning use of the language. Their stylistic and contextual structure requires analysis. Stylistic features of the writer provide important contributions to analysis. The analysis of the literary texts, as aesthetic texts, is different from the other texts. These texts created with an aesthetic care should be approached sensitively; their structural and fictional features should be examined in detail. While writer concretizing his/ her mental designs s/he has to offer the best conditions to communicate with the reader. In this case the style of the writer comes into play.

By the expression of Dijk, "Style is the textual result of choices between alternative ways of saying more or less the same thing by using different words or a different syntactic structure." (115 - 116). ${ }^{4}$ As Todorov transferred from Veselovsky, the superiority of the style is to be able to fit the most thought into the least word. (2010: 75). In the opinion of Leech and Short, "The distinction between 
what a writer has to say, and how it is presented to reader, underlines one of the earliest and most persistent concept of style: that of style as the 'dress of thought'. (1981: 15). By the expression of the writers,

[i] Style is a way in which language is used: ie it belongs to parole rather than to langue.

[ii] Therefore style consists of choices made from repertoire of the language.

[iii] A style is defined in terms of a domain of language use ( $e g$ what choices are made by a particular author, in a particular genre, or in a particular text).

[iv] Stylistics (or the study of style) has typically (as in this book) been concerned with literary language.

[v] Literary stylistics is typically (again, as in this book) concerned with explaining the relation between style and literary or aesthetic function.

[vi] Style is relatively transparent or opaque: transparency implies pharaphrasability; opacity implies that a text cannot be adequately pharaprased, and that interpretation of the text depends greatly on the creative imagination of the reader.

[vii] Stylistic choice is limited to those aspects of linguistic choice which concern alternative ways of rendering the same subject matter. (1981: 38 - 39).

Every literary type has its own language use. With the expression of Leech and Short, every analysis of style is an attempt to find the artistic principles underlying a writer's choice of language. All writers and all texts have their individual qualities (1981: 74).

a. Syntactic Style: Joyce generally uses short sentences. His sentences are not complex. Sentences which consist of one predicate and one subject or a single word such as She was tired.(3), Few people passed.(4), Everything changes.(16), Home!(18) "Come!"(116), are in majority.

Exclamation sentences: Joyce uses 11 exclamation sentences where the tone of the text is augmented.

Interrogative sentences: Joyce uses 5 interrogative sentences that have a function including readers to reading action.

b. Linguistic, Semantic Style: Short story structure requires symbolic 
uses, literary techniques and arts. Because it is short and text producer has to say a lot with fewer words.

Joyce is a modernist writer. He uses flashback and flashforward techniques to express Eveline's variable mood. While flashback is a scene that takes the narrative back in time; flashforward is a scene that takes the narrative forward in time from the current point in the story. These are way to give the reader a look into Eveline's past and future. She is a young girl stuck between choosing a life of regret with her father or going away and starting a new life with her lover. Then she constantly thinks about her past and future. This indicates her indecision: to stay at home or to leave home.

The current point of this story is the moment Eveline sits at the window one evening. Flashbacks and flashforwards happen during this time. The writer prefers as particular narrative techniques, stream of consciousness and internal monologs; free representation of the thoughts, inner conflicts, sensations, emotions and passions of the character, while reflecting Eveline's feelings and thoughts. In the story, past, present and future are intertwined. Stream of consciousness expressed by Tosun (2014: 68 - 69) as critical language of modernism, is both the name of the settling account with tradition and the means of reflection of new status of the modern human. The pioneers of this technique are modernist writers.

Implicit sentences; sudden and continuous moving between past and future in a parallel form to the tides of consciousness; the complicated formal structure of the text require attention as if a poem is read. In the text written with stream of consciousness that Tosun expressed as "An existential settlement, penetration into the spirit of things, enlightenment and discovery journey" (2014: 59), while story character girl's mental expressions in different times are narrated by implicit expressions; her perception of objects around her for example 'the dust, familiar objects; the yellowing photograph of the priest hung on the wall' are expressed through the reflection of consciousness. Maybe while evaluating the present, the placing of the narrative in a time as short as the time of those that are thought during a mental journey to the past, and uncertainty in time perception support the technique of stream of consciousness.

Joyce uses many symbolic structures, which are different from their literal meaning. Symbols acquire a specific connotation, which is defined by the context 
in which they are used. From the beginning of the story the symbols of decay (dusty cretonne) and paralysis (her cheek pale and cold, a nausea in her body, passive, like a helpless animal) are presented. 'Window' symbolizes internal and external world. "Bright brick houses with shining roofs" symbolize changes in the life: Once there was a 'field' in place of these houses. 'Dust and dusting' represent the daily routine, the monotony of Eveline's life and Eveline's failure to separate her current life from the past. Though she cleans the dust, it always returns. 'Music', mentioned by way of reference to the harmonium, to a musical she sees with Frank, and to the familiar street organ music, is important for Eveline. Music is the repetition of the past in the form of 'Street organ music' that reminds Eveline her promise to her mother "to keep the home together as long as she could". It symbolizes both the world beyond Eveline's window and her memory of her dying mother. 'Evening and night-boat' are symbols of transition between Eveline's current life and the one they planned with her lover. 'Sea' is also a symbol that separates Ireland from the outside world and functions as a barrier between her present life and the one she desires to have. Buenos Ayres represents Eveline's fear of the unknown while Ireland represents her spiritual paralysis.

At the same time Eveline's current life in Ireland, near her father symbolizes tradition while her probable life with her lover Frank in Buenos Ayres symbolizes modernism. Though Eveline is weary of tradition she is afraid of modernism, which is unknown for her. Her fear of taking a chance, fear of the unknown and of change are hesitation for modernism. Tradition provides Eveline her basic needs such as shelter, food etc. and is known, reliable for her despite it is described as an unbearable and monotone life. In the face of tradition modernism is unreliable since it is described, as a life in an unknown country beyond ocean though Eveline desires it. Adhering to the good aspects of the tradition and cautious accepting of modernism are suggested.

'Evening, dusty, bad, fool, tears, danger, violence, palpitations, dead, squabble, trouble, hard work, hard life, undesirable, terrible, old, night, night boat, close, illness, dark room, sick room, damned, pitiful, sacrifice, craziness, foolish, terror, escape, unhappy, black mass, pale, cold, distress, nausea, cry, anguish, helpless animal, to hunt, to threat, to cry, to weary, to forbid, to quarrel, to tumble' are dysphoric words supporting the pessimistic tone of the text. 
In the story the phrase "Derevaun Seraun! Derevaun Seraun!"(93) can be evaluated as proverb. "Gifford notes that Patrick Henchy believes the words to be corrupt Gaelic for "the end of pleasure is pain," and Roland Smith thinks they are corrupt Irish, meaning "the end of the song is raving madness."' (Tigges 1994: 102).

\section{Literary arts:}

And yet during all those years she had never found out the name of the priest whose yellowing photograph hung on the wall above the broken harmonium beside the coloured print of the promises made to Blessed Margaret Mary Alacoque.(21) She felt her cheek pale and cold and, out of a maze of distress, she prayed to God to direct her, to show her what was her duty.(109)

There are several religious allusions. 'The priest, Blessed Margaret Mary Alacoque and Eveline's pray to God to direct her' are reminder of the religious feelings in Irish family of Eveline.

"The evening has invaded the avenue" is used as a metaphor.

"Like a helpless animal" is another metaphor sample.

c. Point of View: The story is told from the third-person limited point of view, which is a method of storytelling in which the narrator knows the thoughts and feelings of the main character, Eveline. This point of view is a useful literary device in which narrator lets the reader know information about main character and the reader sees the setting and circumstances through her eyes, and the reader's feelings change with Eveline's. It tends to disappear through the use of free indirect speech in Eveline's interior monologues.

2. 2. 9. Summary: The summarization of a text is the indication of the understanding of the text. Dijk gives a list of major summarizing rules:

1- Names are generalized and substituted by indefinite description or variables: e.g. "a man", "somewhere in Italy".

2- Location descriptions are deleted: e.g. "in a (beautiful) village."

3- Full identifying proposition are reduced to arguments: e.g. "there lived a rich man..." "a rich man..."

4- Summarizing propositions, as redundant information, are deleted.

5 - All preparatory actions which are not presupposed by other propositions of the story are deleted. 
6- Emotional expressions are deleted.

7- Mental planning expressions (intentions, purposes) are deleted if they are identical with the description of the actions planned.

8-All paraphrasing propositions are deleted.

9- Qualifications and comparisons of actions are deleted if entailed by the action descriptions.

10- Expressions of possible alternative courses of events or actions are deleted.

11- Propositions of conventionally following consequences of action are deleted.

12- Component actions which are not presupposed by other actions are integrated into global action description.

13- Non-reducible actions which are not presupposed by following actions are deleted.

14- Time indications are deleted or substituted by variable.

15- Atmosphere and weather descriptions are deleted if they do not denote events causing major actions.

16- Descriptions of normal courses of events or actions are deleted.

17- Descriptions of the way actions are performed are deleted.

18- Description of bodily states are deleted or integrated in a modifier (adverb, adjective).

19- Direct or indirect description of dialogue is deleted (1976: 564-565).

Eveline is a young girl, of 19 years old. She sits and looks out of the window watching the evening invade the avenue. She thinks about her life, her childhood. She and her brothers are now grown up, and her mother is dead. She works very hard, at a store and also at home. She has mixed feelings about her father who often threatens her with violence or sometimes can be kind. Her brother Ernest is dead and other brother Harry is often away on business so there is no one to protect her. She takes care of two young siblings and her elderly father; gives over her whole salary to her father, but her father is always accusing her of wasting money and being foolish.

She plans to leave Ireland with her lover Frank who is a sailor. Frank treats her respectfully and with great tenderness and asks her to escape with him to 
Buenos Ayres. Still, she loves her father and regrets the idea of leaving him in his old age. The epiphany takes place when she listens to the sound of a street organ that reminded in her the promise made to her mother before her death, "to keep the home together as long as she could." She remembers her mother's death and life of commonplace sacrifices closing in final craziness as a repetition of the enigmatic phrase "Derevaun Seraun!"

Eveline has two choices, to stay with her family and to live the monotony of her life or go on an adventure with a sailor and explore new possibilities and a promising life, away from the odour of dusty cretonne. But at the station, with the boat ready to leave, she is paralyzed, figuratively speaking; she is stuck in the repetition of her daily life and unable to change. She cannot go; the world outside Ireland is too frightening. Frank calls to her, trying to get her to board but she stays at the dock and merely stares at him as if he is a stranger.

2. 2. 10. Conclusion Sentence: Final sentence, Her eyes gave him no sign of love or farewell or recognition.(129), is conclusion sentence indicating the uncertainty of Eveline's feelings, her inability to escape from the past and her family which results in the paralysis at the end of the story.

2. 2. 11. Motif/Theme: Motives: Memory, home, father, mother, money, fellow, indecision, guilt, responsibility, epiphany, faith, doubt, escape, station, paralysis are determined as the motives of the text.

Themes: 'The prison of routine; self-sacrifice', 'The difficult life of the woman in patriarchal society' are determined as sub-themes of the text. The main theme can be expressed, as 'Responsibilities and emotional commitments require sacrifices.'

\section{Conclusion:}

During the textlinguistic analysis of the short story,

1- Short story makes the students' reading work easier since it is short when compared with other literary types. Students' world knowledge about different culture becomes larger.

2- Students can reach socio-cultural and historical information such as 'Irish Potato Famine' and literary movement and life of its writer, while searching background of the story. 
3- Students vocabularies become richer and the process of word learning become shorter since they learn the words in their context with their synonyms, near synonyms, antonyms or in the form of general words, superordinate and subordinate terms or partial reiteration of the words. Furthermore the poetic language of the contemporary short story facilitates word learning since in this type the repetitions of parallel structures give a poetic rhythm to the story and are easier to learn.

4- Students remember and renew their grammatical information while searching reference items such as personal, demonstrative, reflexive and possessive pronouns; demonstrative and possessive adjectives; connective elements; grammatical tenses; inverse sentence structures; element ellipsis etc.

5- Students use continuously target language during the analysis of the text especially while inferring from implicit expressions; speaking about the title, function, topic, key words, schema, topic change markers, topical sentences, conclusion sentence, motives and themes of the text; analyzing stylistic features of the writer and summarizing the text, in the macrostructure of the text.

6- Students can easily reach multiple layers of meaning of the deep structure of the text underlying its surface structure since textlinguistic analysis requires a close reading of the text.

7- Students' awareness of a literary text's narrative construction is realized while enabling them not to use only the target language but also to understand messages of text producer by applying this method.

8- While investigating stylistic features of the writer, students can learn sentence types in syntactic stylistic features and literary arts, idioms, proverbs in semantic stylistic features.

9- Students' text producing skills are developed because they encounter many texts of the different writers.

10- Both in native language and foreign language teaching, the fluent and correct use of the language is important as well as its grammar. Textlinguistic analysis of the short stories that allow students to develop their basic language skills such as reading, writing, listening, and speaking and to interpret text, to 
learn the grammar of the language, to increase vocabulary is effective and popular method that make easier language teaching.

Eveline is a well-prepared text sample, which can be analyzed through textlinguistic criteria by students. It is suggested to use in language teaching. 


\section{References}

Aksan, Doğan (1993), Şiir Dili ve Türk Şiir Dili, Ankara: Be-Ta Basım Yayım A.Ş.

Aydın, İlker - Torusdağ, Gülşen (2014), "Türkçe Öğretimi Çerçevesinde Yazınsal Bir Metin Çözümleme Örneği Olarak Refik Halit Karay’ın Garip Bir Hediye'si”, Teke Dergisi, Say1 3/4, 109-134.

Beaugrande, Robert Alain de - Dressler, Wolfgang Ulrich (1981), Introduction to Text Linguistics, London and New York: Longman.

Çetişli, İsmail (2006), “““Edebiyat Eğitimi”nde “Edebî Metin”in Yeri ve Anlamı”, Millî Eğitim, Y11 34, S. 169, Ankara: Milli Eğitim Bakanlığı Yayınları. http://dhgm.meb.gov.tr/yayimlar/dergiler/Milli_Egitim_Dergisi/169/ismail.pdf Access Date: 19. 04. 2018.

Dijk, Teun A. van (1976), "Narrative Macro-Structures", PLT: A Journal for Descriptive Poetics and Theory of Literature 1, North-Holland Publishing Company, 547-568.

Dijk, Teun A. van - Kintsch, Walter (1983), Strategies of Discourse Comprehension, London: Academic Press.

Dijk, Teun A. van (2002), “The interdisciplinary study of news as discourse”, A Handbook of Qualitative Methodologies for Mass Communication Research, Ed. By Klaus Bruhn Jensen-Nicholas W. Jankowski, USA and Canada: Routledge, 108-119.

Dilidüzgün, Şükran (2008), Türkçe Öğretiminde Metindilbilimsel Bağlamda Uygulamalı Bir Yaklaşım, Doktora Tezi, İst. Üniversitesi, Sosyal Bilimler Enstitüsü.

Erden, Aysu (2010), Kısa Öykü ve Dilbilimsel Eleştiri, Ankara: Bizim Büro Yay.

Günay, Doğan (2007), Metin Bilgisi, İstanbul: Multilingual.

Halliday, M. A. K. - Hasan, Ruqaiya (1976), Cohesion in English, London: Longman.

Kıran, Zeynel - Kıran, Ayşe Eziler (2010), Dilbilime Giriş, Ankara: Seçkin Yay.

Krsteva, Marija - Kukubajska Marjia Emilija (2014), "The Role of Literature in Foreign Language Acquisition", Science Direct Procedia - Social and Behavioral Sciences 116, $3605-3608$.

Lazar, Gillian (2009), Literature and Language Teaching UK: Cambridge University Press.

Leech, Geoffrey N. - Short, Michael H. (1981), Style in Fiction, London and New York: Longman.

Sage, Howard (1987), Incorporating Literature in ESL Instruction. Language in Education: Theory and Practice, No. 66 New Jersey: Prentice-Hall, Inc.

Onursal, İrem (2003), “Türkçe Metinlerde Bağdaşıklık ve Tutarlılık”, Günümüz Dilbilim Çalışmalarl, Dilbilim Dizisi, İstanbul: Multilingual Yay.

Öztokat, Nedret Tanyolaç (2005), Yazınsal Metin Çözümlemesinde Kuramsal Yaklaşımlar, İstanbul: Multilingual. 
Şenöz, Canan Ayata (2005), Metindilbilim ve Türkçe, İstanbul: Multilingual.

Tigges, Wim (Fall, 1994), ““'Derevaun Seraun!”: Resignation or Escape?”, James Joyes Quarterly, Vol. 3, No. 1, Published by University of Tulsa, 102-104.

Todorov, Tzvetan (2010), Çev. Mehmet Rifat-Sema Rifat, Yazın Kuramı, İstanbul: Y. K. Y.

Tosun, Necip (Ekim, 2014), Modern Öykü Kuramı, Ankara: Hece Yay.

Yıldırım, Ali - Şimşek, Hasan (2003), Sosyal Bilimlerde Nitel Araştırma Yöntemleri, Ankara: Seçkin Yay.

http://discourses.org/OldArticles Access Date: 20. 04. 2018.

https://evelinehyperfiction.weebly.com/derevaun-seraun.html Access Date: 20. 04. 2018.

http://irishgaelictranslator.com/translation/topic1069.html Access Date: 23. 10. 2017

http://onestopenglish.com/methodology/methodology/teaching materials/teaching-materialsusing-literature-in-the-efl/-esl-classroom/146508.article Access Date: 20. 04. 2018 